\title{
Design of Novel Hybrid Vitamin C Derivatives: Thermal Stability and Biological Activity
}

\author{
Kazuo MorisaKI* and Shoichiro OZAKI \\ Department of Applied Chemistry, Faculty of Engineering, Ehime University, Matsuyama 790, Japan. \\ Received December 22, 1995; accepted April 26, 1996
}

\begin{abstract}
Novel hybrid L-ascorbic acid (vitamin C) derivatives with other biologically active substances, 5-hydroxy2-hydroxymethyl- $\beta$-pyrone (kojic acid) and $\alpha$-tocopherol (vitamin $\mathrm{E}$ ), linked at the $\mathrm{C}-2$ or $\mathrm{C}-3$ hydroxyl group were synthesized, and their thermal stability and inhibitory effects on tyrosinase activity, active oxygen species (AOS), and free radicals were estimated in vitro. It was found that a hydrophilic derivative, 2-O-(5-hydroxy- $4 \mathrm{H}$-pyran4-one-2-methyl)-L-ascorbic acid (1), exhibited good thermal stability and inhibitory activities against tyrosinasecatalyzed melanin formation, AOS, and free radicals compared to vitamin $\mathrm{C}$ and its conventional derivatives (such as the 2-phosphate, 6-stearate and 2,6-dipalmitate, and 2-O-octadecylascorbic acid), as well as vitamin $\mathrm{E}$, kojic acid, and arbutin. It is apparent that 1 has the biological properties of vitamin $C$ and kojic acid, and acts synergistically. The hydroxyl groups at the $C-3$ position of the vitamin $C$ moiety and the $C-5$ position of the kojic acid moiety are critical for the biological activities. We consider that the kojic acid moiety of 1 counterbalances the diminution of the biological activity due to shielding of the biologically important C-2 hydroxyl group of the vitamin $\mathbf{C}$ moiety. In addition, the thermal stability was significantly improved relative to not only vitamin $\mathbf{C}$ but also kojic acid. Further, a lipophilic derivative, 3- $O$ - $[(\alpha$-tocopheryloxy)-2-hydroxypropyl $]$-L-ascorbic acid, 2 , was far more stable than vitamin $\mathrm{C}$ and its typical lipophilic derivatives. Compound 2 exhibited almost the same inhibitory activities against tyrosinase-catalyzed melanin formation, AOS, and free radicals as typical lipophilic derivatives, although these biological activities of 2 were lower than those of vitamin $\mathrm{C}$.
\end{abstract}

Key words L-ascorbic acid; kojic acid; $\alpha$-tocopherol; melanogenesis; tyrosinase; active oxygen species

Recently, depletion of the ozone layer in the stratosphere has allowed an increasing amount of solar ultraviolet (UV) radiation $(290-400 \mathrm{~nm})$ to reach the Earth's surface. UV radiation has been shown to generate active oxygen species (AOS) such as superoxide anion radicals, hydrogen peroxide, hydroxyl radicals, and singlet oxygen or free radicals in living organisms. ${ }^{1)}$ AOS and free radicals derived from the biological utilization of $\mathrm{O}_{2}$ are responsible for oxidative injury to enzymes, lipid membranes, protein, and DNA in living cells, ${ }^{2)}$ and participate in the development or exacerbation of various kinds of diseases. ${ }^{3)}$ Furthermore, oxidative stress or damage induced by free radicals is related to the aging process called dermatoheliosis. ${ }^{4)}$ Tyrosinase (tyrosine hydroxylase, dopa oxidase, and 5,6-dihydroxyindole oxidase) activity is enhanced by AOS, resulting in excess melanin formation, ${ }^{5)}$ which is a natural biological protecting mechanism, though melanin peroxidizes phospholipid in the presence of $\mathrm{Fe}^{3+}$, resulting in cell death among dopaminergic neurons. ${ }^{6}$ Under normal conditions, cells and tissues are protected from the attack of AOS and free radicals by various enzymes such as superoxide dismutase (SOD), catalase, and peroxidase, as well as $\alpha$-tocopherol (vitamin E), glutathione, and L-ascorbic acid (vitamin C). ${ }^{3,7)}$

It is known that vitamin C (3) scavenges AOS and free radicals as a chain-breaking antioxidant ${ }^{8)}$ and inhibits tyrosinase-catalyzed melanin formation by reduction of the intermediate, dopaquinone ( $\alpha$-amino-3,4-dioxo-1,5cyclohexadiene-1-propionic acid), as well as eumelanin, in melanogenesis. ${ }^{9}$ ' Furthermore, there is considerable evidence that vitamin $\mathrm{C}$ is important in the prevention of a large number of chronic diseases, such as cancer, cerebral apoplexy, diabetes, atopic dermatitis, myocardial infarction, and AIDS. ${ }^{10)}$ These characteristic biological activities

* To whom correspondence should be addressed. of vitamin $\mathrm{C}$ are derived from the enediol structure with its strong electron-donating ability. Vitamin $\mathrm{C}$ is reversibly metabolized to dehydro-L-ascorbic acid via monodehydro$\mathrm{L}$-ascorbic acid in a series of oxidative processes (Chart 1). The redox reactions among these three ascorbates are closely related to their biological activity as vitamin C.

The well-known susceptibility of vitamin $\mathrm{C}$ to thermal and oxidative degradation has led to interest in derivatives with increased stability in vitro, while maintaining the inherent biological activity in vivo. In particular, the chemical modification of hydroxyl groups of vitamin $\mathrm{C}$ is of interest, and numerous stable derivatives of vitamin $\mathrm{C}$ have been reported. ${ }^{11-21)}$ Generally, the partial modification of the enediol system gives two isomers, both of which show markedly decreased reducing power and are therefore stabilized against oxidation, and vitamin $\mathrm{C}$ activities tend to be reduced with increasing number of substituents in the molecule. ${ }^{11)}$ Among these derivatives, the magnesium salt of ascorbic acid 2-phosphate (APC-3, 14) is available as a hydrophilic antioxidant ${ }^{9,12,13)}$ (Fig. 1). Furthermore, 2-O- $\alpha$-D-glucopyranosylascorbic acid (AA$2 \mathrm{G})$ has good stability and a potent inhibitory effect on tyrosinase in vivo. ${ }^{14)}$ Ascorbic acid 6-stearate (15) and 2,6-dipalmitate (16) have been widely used as lipophilic antioxidants ${ }^{15)}$ (Fig. 1). These compounds are relatively stable in vitro and exhibit vitamin $C$ activity after enzymatic degradation to free vitamin $\mathrm{C}$ by phosphatase, glucosidase, or esterase in vivo. 3-O-(Dodecylcarbomethyl)ascorbic acid $(\mathrm{HX}-0112)^{16)}$ and 2-O-octadecylascorbic acid (CV-3611, 17) ${ }^{17)}$ have been developed as new lipophilic antioxidants, which exhibit vitamin $\mathrm{C}$ activity without enzymatic degradation.

It is well-known that vitamin $\mathrm{E}(\mathbf{1 1})$ acts as a synergistic antioxidant in conjunction with vitamin $\mathrm{C}$ to suppress lipid

(C) 1996 Pharmaceutical Society of Japan 


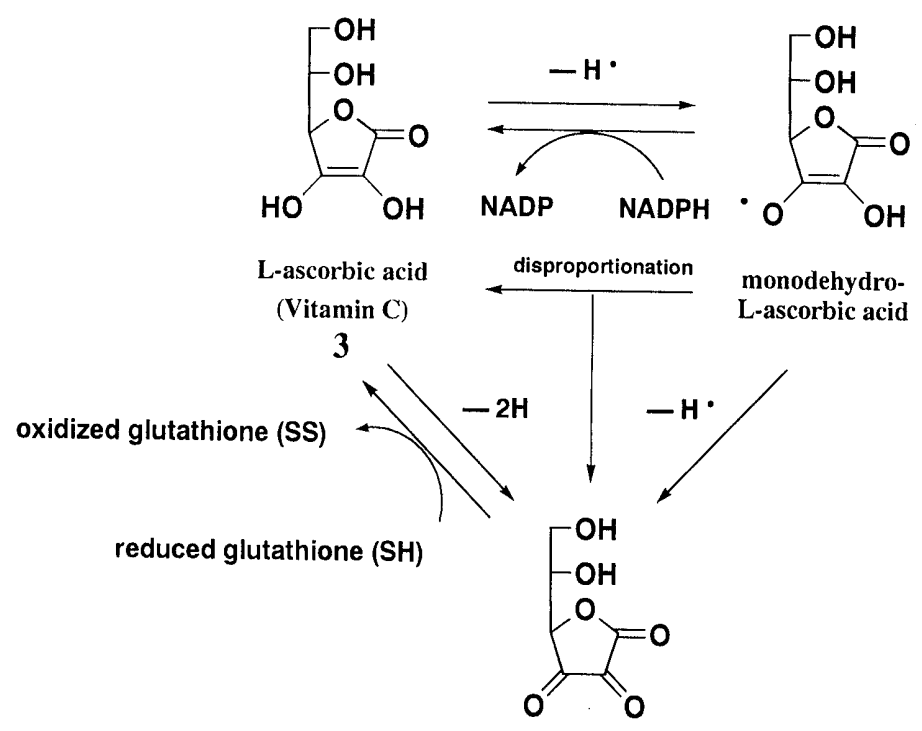

dehydro-L-ascorbic acid

Chart 1. Reversible Metabolic Pathway of L-Ascorbic Acid (3)<smiles>O=C1OC2C(O)C(CO)C(O1)C2O</smiles>

3

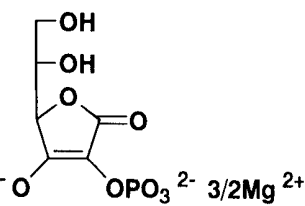

14<smiles>CCCCCCCCCC(=O)OCC(O)C1OC(=O)C(O)=C1O</smiles>

15

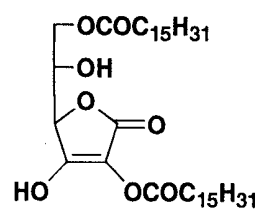

16<smiles>O=C1OC2OC(C1O)C(CO)C2O</smiles>

17<smiles>O=c1cc(CO)occ1O</smiles>

6<smiles>Cc1c(C)c2c(c(C)c1O)CCC(C)(CCCC(C)CCCC(C)CCCC(C)C)O2</smiles>

11<smiles>OC[C@H]1O[C@H](Oc2ccc(O)cc2)[C@H](O)[C@@H](O)[C@@H]1O</smiles>

18

Fig. 1. Typical Inhibitors of Melanin Formation, and Scavengers of AOS or Free Radicals

peroxidation in the cell membrane. ${ }^{18)}$ Recently, two more effective inhibitors of tyrosinase, kojic acid (5-hydroxy-2hydroxymethyl- $\beta$-pyrone, 6) and arbutin (hydroquinone$\beta$-D-glucopyranoside, 18) have been reported (Fig. 1). Kojic acid, isolated from fermentative products of Aspergillus species, inhibits tyrosinase due to chelation of its copper, ${ }^{22)}$ which is indispensable for tyrosinase activity. ${ }^{5)}$ Arbutin, isolated from dried leaves of Bergenia crassifolia Fritsch (Saxifragaceae), suppresses the expression and synthesis of tyrosinase. ${ }^{23)}$

Based on this background, we designed and synthesized a novel series of hybrid vitamin $\mathrm{C}$ derivatives linking these biologically active substances (kojic acid and vitamin E) at the C-2 or C-3 hydroxyl group, which are crucial for both stability and biological activity, with a view to simultaneously improving the stability and preventing diminution of activity. The stability and inhibitory effects of the products on tyrosinase activity, and on AOS and free radicals in vitro, were evaluated.

\section{Results and Discussion}

Synthesis 2-O-(5-Hydroxy-4H-pyran-4-one-2-methyl)-L-ascorbic acid (1) was synthesized in five steps from kojic acid (6) as shown in Chart 2. Selective protection of the hydroxyl group at the C-5 position as the benzyl ether was carried out by Kawase's method to afford 7 in $87 \%$ yield. ${ }^{24)}$ Successive chlorination of 7 by using the $\mathrm{CCl}_{4}-$ $\mathrm{PPh}_{3}$ system exclusively gave 8 in $73 \%$ yield, whereas chlorination with thionyl chloride resulted in partial allylic rearrangement. Condensation of 8 with 3-O-benzyl-5,6-Oisopropylidene-L-ascorbic acid (5) in the presence of $\mathrm{K}_{2} \mathrm{CO}_{3}$ in dimethyl formamide (DMF) afforded 9 in $92 \%$ yield. Removal of protecting groups was achieved by acid hydrolysis followed by catalytic hydrogenation to afford the hydrophilic derivative 1 in $98 \%$ and $84 \%$ yield, respectively.

Compound 5 was synthesized in two steps from $\mathrm{L}$ ascorbic acid (3) as shown in Chart 3. The hydroxyl groups at the $\mathrm{C}-5$ and $\mathrm{C}-6$ positions were protected with acetone by Jung's method to yield 5,6- $O$-isopropylidene-L-ascorbic 


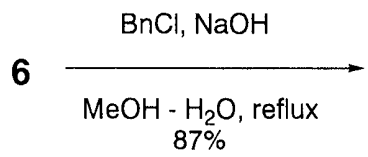<smiles>O=c1cc(CO)occ1OCc1ccccc1</smiles>

7

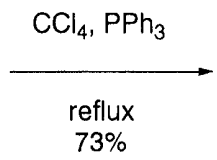

$73 \%$<smiles>O=c1cc(CCl)occ1OCc1ccccc1</smiles>

8<smiles>CC1(C)OCC2OC1C(OCc1ccccc1)=C(OCc1cc(=O)c(OCc3ccccc3)co1)C2=O</smiles>

9<smiles>O=C1OC(COc2cc(=O)c(Cc3ccccc3)co2)C(OCc2ccccc2)=C1OCc1ccccc1</smiles>

10

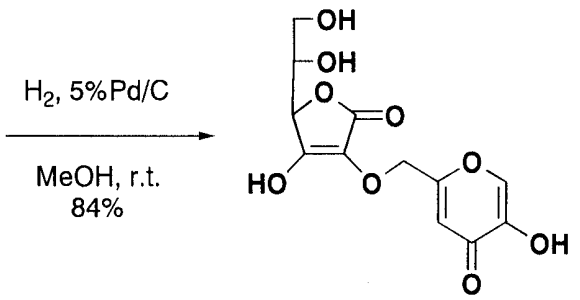

1

Chart 2

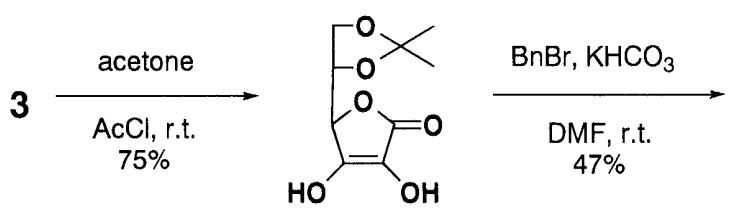

4<smiles>CC1(C)OCC2OC1C(Oc1ccccc1)C(O)=C2O</smiles>

5

Chart 3<smiles>Cc1c(C)c2c(c(C)c1OCC1CO1)CCC(C)(CCCC(C)CCCC(C)CCCC(C)C)O2</smiles><smiles>Cc1c(C)c(OCC(O)COC2=C(O)C(=O)OC2C2COC2(C)C)c(C)c2c1CCC(C)(CCCC(C)CCCC(C)CCCC(C)C)O2</smiles>

13<smiles></smiles>

2

Chart 4

acid (4) in $75 \%$ yield. ${ }^{25}$ Compound 4 was protected as the benzyl ether by using benzyl bromide in the presence of $\mathrm{KHCO}_{3}$ in $\mathrm{DMF}$ to give 5 in $47 \%$ yield.

3-O-[3-[[3,4-Dihydro-2,5,7,8-tetramethyl-2-(4,8,12-trimethyltridecyl)-2H-1-benzopyran-6-yl]oxy]-2-hydroxypropyl]-L-ascorbic acid (2) was synthesized in three steps from vitamin $E$ (11) as shown in Chart 4. Alkylation of 11 with $S$-(+)-epichlorohydrin in the presence of $\mathrm{NaOH}$ in dioxane gave the corresponding glycidyl ether (12) in $92 \%$ yield. Use of a lower substrate concentration $(<1 \mathrm{M})$ gave the chlorohydrin derivative simultaneously. Condensation of 12 with the vitamin $\mathrm{C}$ derivative 4 in the presence of $\mathrm{NaHCO}_{3}$ and a catalytic amount of 4-dimethylaminopyridine (DMAP) in dioxane afforded 13 in $60 \%$ yield. Subsequent removal of the protecting group was achieved by acid hydrolysis to yield the lipophilic derivative 2 almost quantitatively.

Physicochemical, Biological, and Photophysical Prop- 
<smiles>NC(Cc1ccc(O)cc1)C(=O)O</smiles>

L-Tyrosine

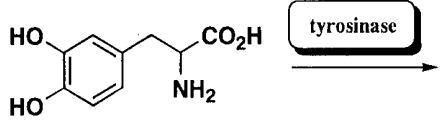

L-Dopa<smiles>NC(CC1=CC(=O)C(=O)C=C1)C(=O)O</smiles>

Dopaquinone

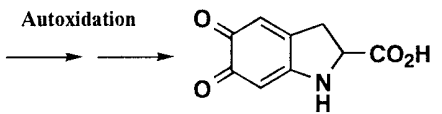

Dopachrome

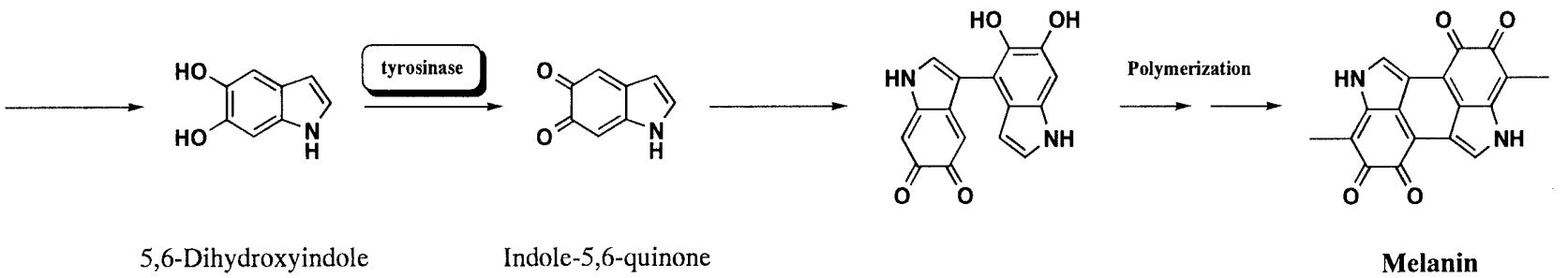

Chart 5. Mechanism of Melanogenesis

Table 1. Stability of Vitamin C Derivatives in Aqueous Solution

\begin{tabular}{cccc}
\hline \hline & \multicolumn{3}{c}{ Remaining $(\%)^{b)}$} \\
\cline { 2 - 4 } Compound $^{a)}$ & 1 month & 2 months & 3 months \\
\hline $\mathbf{1}$ & 95.4 & 85.1 & 80.0 \\
$\mathbf{2}$ & 88.5 & 82.3 & 79.8 \\
$\mathbf{1 4}^{()}$ & 100 & 98.9 & 95.5 \\
$\mathbf{1 5}^{c)}$ & 25.5 & 17.3 & 15.5 \\
$\mathbf{1 6}^{c)}$ & 46.2 & 22.3 & 21.7 \\
$\mathbf{3}^{()}$ & 89.2 & 77.7 & 37.1 \\
$\mathbf{6}^{()}$ & 98.2 & 80.8 & 46.9 \\
\hline
\end{tabular}

a) The test compound was dissolved in $\mathrm{EtOH}: \mathrm{H}_{2} \mathrm{O}=1: 1(\mathrm{v} / \mathrm{v})$ to give a con centration of $1 \mathrm{~mol} \%$. b) The resulting solution was stored at $60^{\circ} \mathrm{C}$ for 3 months, and the decrease in concentration was measured by HPLC. c) Reagents (Wako Pure Chemical Industries Ltd.) were used without purification. d) Reagents (Tokyo Chemical Industry Co., Ltd.) were used without purification.

erties The thermal stability of $\mathbf{1}$ and $\mathbf{2}$ was tested by using a $1 \mathrm{~mol} \%$ solution of the test compound in $\mathrm{EtOH}$ : $\mathrm{H}_{2} \mathrm{O}=1: 1(\mathrm{v} / \mathrm{v})$ at $60^{\circ} \mathrm{C}$, and compared with that of reference compounds $3, \mathbf{1 4}, \mathbf{1 5}, \mathbf{1 6}$, and $\mathbf{6}$. Stability was evaluated on the basis of remaining ratio measured by HPLC, and the results are shown in Table 1. It was found that about $80 \%$ of 1 and 2 remained intact after 3 months, while $\mathbf{3}$ as well as the typical lipophilic derivatives $\mathbf{1 5}$ and 16 underwent more than $60 \%$ degradation within 3 months. However, the stability of $\mathbf{1}$ and $\mathbf{2}$ was low compared to that of a conventional hydrophilic derivative $\mathbf{1 4}$ (remaining amount $=95.5 \%$ after 3 months). Furthermore, we found that 1 was far more stable than kojic acid (6) (remaining amount $=46.9 \%$ after 3 months). This result means that the stability of $\mathbf{1}$ was significantly improved over both vitamin $\mathrm{C}$ and kojic acid.

Melanogenesis is catalyzed by tyrosinase via the intermediates dopa (3,4-dihydroxyphenylalanine) and dopaquinone from tyrosine, ${ }^{6)}$ and vitamin $\mathrm{C}$ inhibits melanogenesis through the reduction of dopaquinone to dopa. ${ }^{9)}$ These processes are summarized in Chart 5. Therefore, we estimated the inhibitory effect of compounds $\mathbf{1}$ and $\mathbf{2}$ on mushroom tyrosinase activity by using both L-tyrosine and L-dopa as substrates in vitro.

The results on inhibitory activity against tyrosinasecatalyzed oxidation of L-tyrosine are shown in Table 2.
Table 2. Inhibitory Activity against Tyrosinase-Catalyzed Oxidation of L-Tyrosine

\begin{tabular}{|c|c|}
\hline Inhibitor $^{a)}$ & Inhibition $(\%)^{b)}$ \\
\hline 1 & 90.6 \\
\hline 2 & 43.0 \\
\hline $14^{c)}$ & 57.1 \\
\hline $15^{c)}$ & 31.4 \\
\hline $16^{c)}$ & 39.7 \\
\hline $17^{d)}$ & 31.7 \\
\hline $3^{c)}$ & 50.1 \\
\hline $6^{e)}$ & 100 \\
\hline $18^{e)}$ & 52.4 \\
\hline $11^{e)}$ & $<1.0$ \\
\hline $3+6^{f)}$ & 84.7 \\
\hline $3+11^{f)}$ & 48.5 \\
\hline
\end{tabular}

a) A $10^{-3} \mathrm{M}$ sample solution was added to $0.3 \mathrm{mg} / \mathrm{ml}$ L-tyrosine aqueous solution in buffer solution ( $\mathrm{pH} 6.8$ ). b) The resulting solution was added to $1.0 \mathrm{mg} / \mathrm{ml}$ tyrosinase aqueous solution, and incubated at $37^{\circ} \mathrm{C}$ for $20 \mathrm{~min}$. The absorbance of the reaction mixture was measured at $475 \mathrm{~nm}$, and the inhibition was calculated. c) Reagents (Wako Pure Chemical Industries Ltd.) were used without purification. d) This was synthesized by Kato's method. ${ }^{17}$ e) Reagents (Tokyo Chemical Industry Co., Ltd.) were used without purification. f) A mixed solution of 3 $\left(5 \times 10^{-4} \mathrm{M}\right)$ and another substrate $\left(5 \times 10^{-4} \mathrm{M}\right)$ was added to $0.3 \mathrm{mg} / \mathrm{ml}$ L-tyrosine aqueous solution in buffer solution $(\mathrm{pH} 6.8)$.

The inhibitory activity of test compounds was estimated at $10^{-3} \mathrm{M}$. It was found that 1 exhibited potent inhibitory activity (inhibition $=90.6 \%$ ) compared to 3 and its conventional derivatives 14, 15, 16, and 17 (inhibition $<60 \%$ ). Compound 1 was remarkably superior to arbutin (18) (inhibition $=52.4 \%$ ), but slightly inferior to 6 (inhibition $=100 \%$ ). Furthermore, it was found that 1 exhibited almost the same inhibitory activity as a combined system of $\mathbf{3}$ and $\mathbf{6}$ corresponding to an equal molar amount to 1 (inhibition $=84.7 \%$ ). On the other hand, the inhibitory activity of 2 (inhibition $=43.0 \%$ ) was slightly lower than that of 3 (inhibition $=50.1 \%$ ) or that of a combined system of $\mathbf{3}$ and $\mathbf{1 1}$ corresponding to an equal molar amount to 2 (inhibition $=48.5 \%$ ).

The results on inhibitory activity against tyrosinasecatalyzed oxidation of L-dopa are shown in Table 3. The inhibitory activity of test compounds was evaluated at $3 \times 10^{-4} \mathrm{M}$ against tyrosinase, and the $50 \%$-inhibition concentration $\left(\mathrm{IC}_{50}\right)$ was also estimated. It was found that 1 exhibited almost equivalent inhibitory activity (inhibition 
$=43.9 \%, \mathrm{IC}_{50}=3.7 \times 10^{-4} \mathrm{M}$ ) to 3 (inhibition $=38.2 \%$, $\left.\mathrm{IC}_{50}=4.7 \times 10^{-4} \mathrm{M}\right)$. The inhibitory activity of 1 was far higher than that of conventional vitamin $\mathrm{C}$ derivatives $\mathbf{1 4}$, 16, and 17, in which the C-2 hydroxyl group is blocked, with the exception of 15 (inhibition $=31.5 \%, \mathrm{IC}_{50}=$ $9.3 \times 10^{-4} \mathrm{M}$ ). In comparison with typical inhibitors, 1 was greatly superior to 18 (inhibition $=12.8 \%, \mathrm{IC}_{50}=$ $2 \times 10^{-2} \mathrm{M}$ ) in inhibitory activity, but inferior to 6 (inhibition $\left.=59.2 \%, \quad \mathrm{IC}_{50}=1.8 \times 10^{-4} \mathrm{M}\right)$. Furthermore, 1 exhibited almost the same inhibitory activity as a combined system of $\mathbf{3}$ and $\mathbf{6}$ corresponding in molar amount to $\mathbf{1}$ (inhibition $=44.2 \%, \mathrm{IC}_{50}=3.6 \times 10^{-4} \mathrm{M}$ ). On the other hand, the inhibitory activity of 2 (inhibition $=11.4 \%$, $\mathrm{IC}_{50}=2.3 \times 10^{-2} \mathrm{M}$ ) was almost the same as that of $\mathbf{1 8}$, and far lower than that of a combined system of $\mathbf{3}$ and 11 corresponding in molar amount to 2 (inhibition $\left.=26.8 \%, \quad \mathrm{IC}_{50}=1.0 \times 10^{-3} \mathrm{M}\right)$. Thus, $\mathbf{1}$ exhibited

Table 3. Inhibitory Activity against Tyrosinase-Catalyzed Oxidation of $L$-Dopa

\begin{tabular}{|c|c|c|}
\hline Inhibitor $^{a)}$ & $\begin{array}{c}\text { Inhibition }(\%)^{b)} \\
\left(3 \times 10^{-4} \mathrm{M}\right)\end{array}$ & $\mathrm{IC}_{50}, 10^{-3} \mathrm{M}^{\mathrm{c}}$ \\
\hline 1 & 43.9 & 0.37 \\
\hline 2 & 11.4 & 23.49 \\
\hline $14^{d)}$ & 5.5 & $>100$ \\
\hline $15^{d)}$ & 31.5 & 0.93 \\
\hline $16^{d)}$ & 18.9 & 11.68 \\
\hline $17^{e)}$ & 6.5 & $>100$ \\
\hline $\mathbf{3}^{d)}$ & 38.2 & 0.47 \\
\hline $6^{f)}$ & 59.2 & 0.18 \\
\hline $18^{f)}$ & 12.8 & 20.00 \\
\hline $11^{f 1}$ & $<1.0$ & $>100$ \\
\hline $3+6^{g)}$ & 44.2 & 0.36 \\
\hline $3+11^{g)}$ & 26.8 & 1.02 \\
\hline
\end{tabular}

a) Sample solutions $\left(10^{-4}, 3 \times 10^{-4}\right.$, and $\left.10^{-3} \mathrm{M}\right)$ were added to $0.5 \mathrm{mg} / \mathrm{ml} \mathrm{L}$ dopa aqueous solution in buffer solution $(\mathrm{pH} 6.8)$. b) The resulting solution was added to $1.0 \mathrm{mg} / \mathrm{ml}$ tyrosinase aqueous solution, and incubated at $37^{\circ} \mathrm{C}$ for $1 \mathrm{~min}$. The absorbance of the reaction mixture was measured at $475 \mathrm{~nm}$, and the inhibition was calculated, c) The $50 \%$-inhibitory concentration was calculated from the plot of inhibition against $\log$ m. d) Reagents (Wako Pure Chemical Industries Ltd.) were used without purification. e) This was synthesized by Kato's method. ${ }^{17)} f$ ) Reagents (Tokyo Chemical Industry Co., Ltd.) were used without purification. g) A mixed solution of $3\left(5 \times 10^{-4} \mathrm{M}\right)$ and another substrate $(5 \times$ $10^{-4} \mathrm{M}$ ) was added to $0.3 \mathrm{mg} / \mathrm{ml}$ L-tyrosine aqueous solution in buffer solution (pH 6.8). potent inhibitory activity against tyrosinase-catalyzed oxidation of both L-tyrosine and L-dopa. It seems that its high inhibitory activity on melanogenesis is caused by the synergistic effect of the vitamin $\mathrm{C}$ and kojic acid moieties; the 3-enol structure of the vitamin $\mathrm{C}$ moiety presumably reduces dopaquinone to regenerate dopa, while the 5,6-enol structure of the kojic acid moiety deactivates tyrosinase due to chelation of its copper ${ }^{22)}$ (Fig. 2). This synergistic effect was found in a combined system of 3 and 6 (Tables 2 and 3). Consequently, the action of the kojic acid moiety counterbalances the diminution of the tyrosinase-inhibitory activity that arises from blocking of the 2-hydroxyl group of the vitamin $\mathrm{C}$ moiety. On the other hand, it seems that the low inhibitory activity of 2 is caused by the blocking of the key 3-hydroxyl group of the vitamin C moiety. Vitamin E (11) did not suppress tyrosinase-catalyzed oxidation of L-tyrosine and L-dopa at all, as shown in Table 3.

The reducing activity of $\mathbf{1}$ and $\mathbf{2}$ was measured by use of a stable radical, $\alpha, \alpha$-diphenyl- $\beta$-picrylhydrazyl (DPPH), in vitro, and the results are shown in Table 4 . At a high concentration $\left(10^{-3} \mathrm{M}\right)$ corresponding to ten molar amounts with respect to DPPH, 1 and 2 both exhibited

Table 4. Reducing Activity against $\alpha, \alpha$-Diphenyl- $\beta$-picrylhydrazyl

\begin{tabular}{ccc}
\hline Scavenger $^{a)}$ & $\begin{array}{c}\text { Inhibition }(\%)^{b)} \\
\left(10^{-3} \mathrm{M}\right)\end{array}$ & $\mathrm{IC}_{50}, 10^{-6} \mathrm{M}^{c)}$ \\
\hline $\mathbf{1}$ & 97.2 & 10.0 \\
$\mathbf{2}$ & 95.3 & 50.1 \\
$\mathbf{1 5}^{d)}$ & 97.0 & 18.8 \\
$\mathbf{1 6}^{(\mathbf{)}}$ & 68.6 & 281.8 \\
$\mathbf{1 7}^{(\mathbf{)}}$ & 96.4 & 89.1 \\
$\mathbf{3}^{d)}$ & 97.2 & 17.8 \\
$\mathbf{6}^{f)}$ & 14.0 & $>10000$ \\
$\mathbf{1 1}^{f)}$ & 97.0 & 11.6 \\
\hline
\end{tabular}

a) The test compound in DMF was added to $10^{-4} \mathrm{M}$ DPPH in EtOH to prepare $10^{-6}, 10^{-5}, 10^{-4}$, and $10^{-3} \mathrm{M}$ sample solutions. $b$ ) The resulting solution was stirred at $25^{\circ} \mathrm{C}$ for $20 \mathrm{~min}$. The absorbance (OD) of the reaction mixture was measured at $517 \mathrm{~nm}$, and the inhibition was calculated. c) The $50 \%$-inhibitory concentration was calculated from the plot of OD against $-\log \mathrm{M}$. d) Reagents (Wako Pure Chemical Industries Ltd.) were used without purification. e) This was synthesized by Kato's method. ${ }^{17)} f$ ) Reagents (Tokyo Chemical Industry Co., Ltd.) were used without purification.
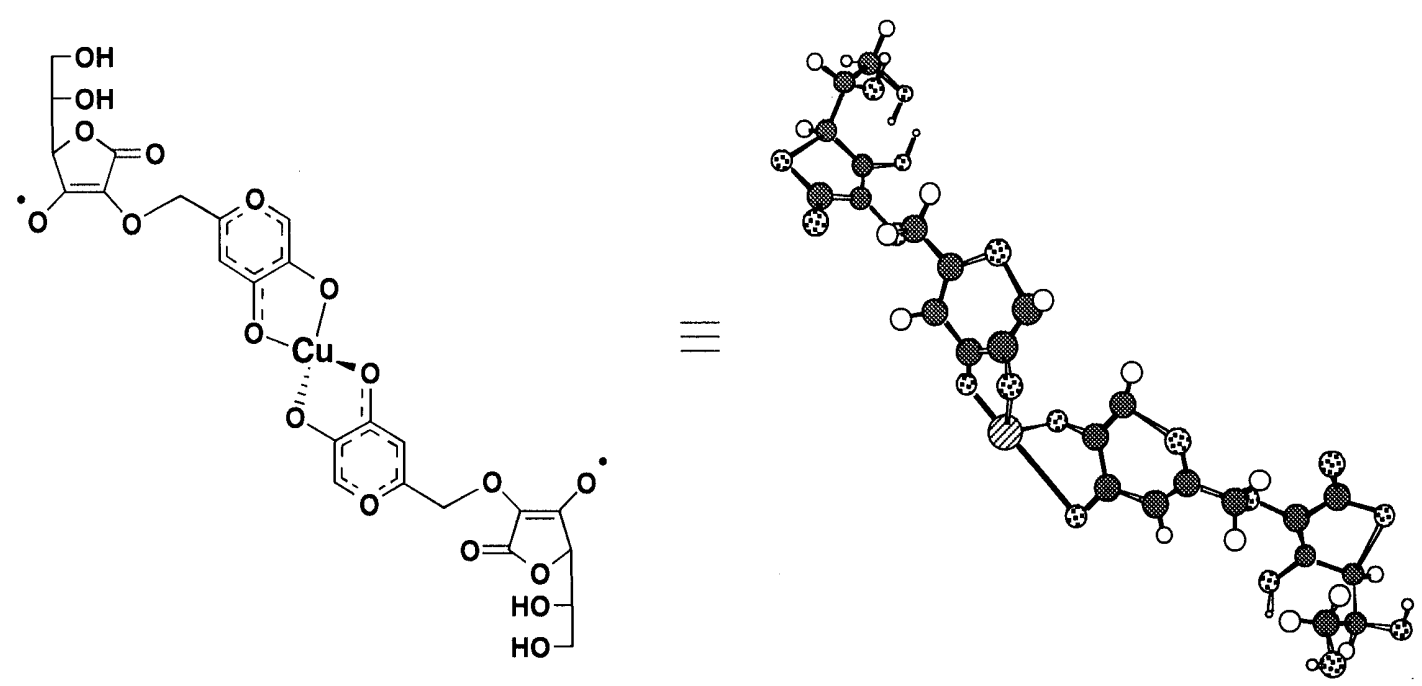

Fig. 2. Proposed Inhibition Mechanism of Tyrosinase-Catalyzed Melanin Formation by $\mathbf{1}$ 
Table 5. Scavenging Activity against Active Oxygen by Nitro Blue Tetrazolium (NBT) Method

\begin{tabular}{|c|c|}
\hline Scavenger ${ }^{a}$ ) & $\begin{array}{c}\text { Inhibition }(\%)^{b)} \\
\left(10^{-6} \mathrm{M}\right)\end{array}$ \\
\hline 1 & 7.0 \\
\hline 2 & 1.8 \\
\hline $14^{c)}$ & 0.7 \\
\hline $15^{c)}$ & 3.6 \\
\hline $16^{c)}$ & 5.9 \\
\hline $17^{d)}$ & 5.2 \\
\hline $\mathbf{3}^{\text {c) }}$ & 5.0 \\
\hline $6^{e)}$ & 3.1 \\
\hline $11^{e)}$ & 10.8 \\
\hline $\mathrm{SOD}^{c)}$ & 95.6 \\
\hline
\end{tabular}

a) Sample solutions $\left(10^{-6}, 10^{-5}, 10^{-4}\right.$, and $\left.10^{-3} \mathrm{M}\right)$ were added to $3 \times 10^{-3} \mathrm{M}$ xanthine buffer solution ( $\mathrm{pH} 10.2), 7.5 \times 10^{-4} \mathrm{M}$ NBT buffer solution, and $3 \times$ $10^{-3} \mathrm{M}$ ethylenediaminetetraacetic acid disodium salt aqueous solution. $b$ ) Each resulting solution was added to $1 \%(\mathrm{v} / \mathrm{v})$ xanthine oxidase suspension in $0.15 \%$ $(\mathrm{w} / \mathrm{v})$ albumin aqueous solution, and incubated at $25^{\circ} \mathrm{C}$ for $20 \mathrm{~min}$. The enzymatic reaction was stopped with $6 \times 10^{-3} \mathrm{M} \mathrm{CuCl}_{2}$ aqueous solution. The absorbance of reaction mixture was measured at $560 \mathrm{~nm}$, and the inhibition was calculated. c) Reagents (Wako Pure Chemical Industries Ltd.) were used without purification. d) This was synthesized by Kato's method. ${ }^{17)}$ e) Reagents (Tokyo Chemical Industry Co., Ltd.) were used without purification.

almost the same reducing activity as $\mathbf{3}$, a conventional derivative 15, and a typical antioxidant, 11 (inhibition $>95 \%)$. In addition, it was found that the $\mathrm{IC}_{50}$ of $\mathbf{1}$ $\left(10^{-5} \mathrm{M}\right)$ was almost the same as that of $3\left(1.8 \times 10^{-5} \mathrm{M}\right)$, $15\left(1.9 \times 10^{-5} \mathrm{M}\right)$, and $11\left(1.2 \times 10^{-5} \mathrm{M}\right)$. Furthermore, 1 exhibited far higher reducing activity than other conventional derivatives, $\mathbf{1 6}$ and $\mathbf{1 7}$. It is apparent that its high reducing activity is not caused by the kojic acid moiety, since kojic acid (6) exhibited little reducing activity towards free radicals, as shown in Table 4 . On the other hand, the $\mathrm{IC}_{50}$ of $2\left(5 \times 10^{-5} \mathrm{M}\right)$ was far higher than that of $\mathbf{3}$, namely the reducing activity was low. It seems that this low reducing activity is caused by shielding of the most active sites against free radicals, the 3-hydroxyl group of the vitamin $\mathrm{C}$ moiety and the 6-hydroxyl group of the vitamin $\mathrm{E}$ moiety, although 11 exhibited considerable reducing activity $\left(\mathrm{IC}_{50}=1.2 \times 10^{-5} \mathrm{M}\right)$.

The scavenging activity of $\mathbf{1}$ and 2 against AOS was measured by the nitro blue tetrazolium (NBT) method depending on enzymatic superoxide anion generation in vitro, and the results are shown in Table 5. The typical scavenger SOD (Cu, Zn-form; M.W. ca. 32000) almost completely scavenged AOS generated by the xanthinexanthine oxidase (XOD) system at $10^{-6} \mathrm{M}$. However, the scavenging activity of other test compounds was too low to allow calculation of the $\mathrm{IC}_{50}$ at concentrations of less than $10^{-3} \mathrm{M}$. Therefore, the scavenging activity of each compound was estimated in terms of the inhibition at $10^{-6} \mathrm{M}$. We found that 1 exhibited almost the same scavenging activity (inhibition $=7.0 \%$ ) as $\mathbf{3}$ (inhibition $=5.0 \%$ ), as did its conventional derivatives $15, \mathbf{1 6}$, and 17. It seems that its high scavenging activity arises from a synergistic effect of vitamin $\mathrm{C}$ and kojic acid, which exhibited only a slight scavenging activity (inhibition $=3.1 \%$ ). On the other hand, the scavenging activity of 2 (inhibition $=1.8 \%$ ) was far lower than that of 3 . This may be because of shielding of the most active sites, i.e., the 3-hydroxyl group of the vitamin $\mathrm{C}$ moiety and the

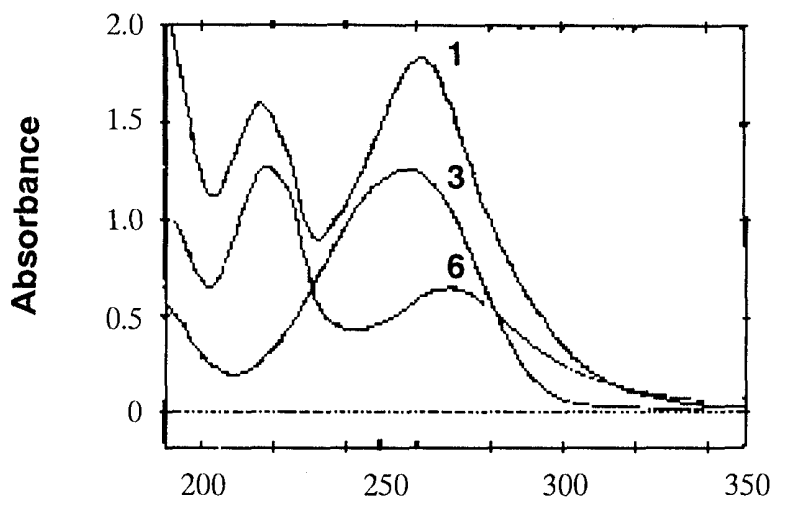

Wavelength $(\mathrm{nm})$

Fig. 3. UV Spectra of Aqueous 3, 6, and 1 at $25^{\circ} \mathrm{C}$

6-hydroxyl group of the vitamin E moiety, although 11 exhibited considerable scavenging activity (inhibition $=10.8 \%$ ).

The UV absorption spectra of vitamin C (3), kojic acid (6), and 1 are shown in Fig. 3. Compounds 3 and 6 exhibited characteristic absorptions at 258, 218 and $268 \mathrm{~nm}$ respectively. Compound $\mathbf{1}$ exhibited absorptions corresponding those of $\mathbf{3}$ and $\mathbf{6}$ at 262 and $217 \mathrm{~nm}$, respectively.

\section{Conclusion}

To improve the thermal stability and simultaneously to avoid diminution of the activity of vitamin $\mathrm{C}$, we designed a novel series of hybrid vitamin $\mathrm{C}$ derivatives in which these biologically active substances (kojic acid and vitamin E) are linked at the C-2 or C-3 hydroxyl group, which predominantly influence both stability and activity. Among these derivatives, 1 exhibited high thermal stability, moderate inhibitory activity against tyrosinasecatalyzed melanin formation, and moderate scavenging activity towards AOS and free radicals in vitro compared to other typical inhibitors and scavengers. It is apparent that $\mathbf{1}$ has the biological properties of both vitamin $\mathrm{C}$ and kojic acid. We regard $\mathbf{1}$ as a promising hydrophilic vitamin $\mathrm{C}$ derivative with high thermal stability and the characteristic biological activity of vitamin $\mathrm{C}$.

The lipophilic derivative $\mathbf{2}$ was far more stable than vitamin $\mathrm{C}$ and its typical lipophilic derivatives. Furthermore, $\mathbf{2}$ exhibited almost the same inhibitory activity against tyrosinase-catalyzed melanin formation and scavenging activities towards AOS and free radicals as those of typical lipophilic derivatives, although these activities of 2 were weaker than those of vitamin $\mathrm{C}$. It seems that the low biological activity of $\mathbf{2}$ is caused by the masking of the biologically active sites, the 3-hydroxyl group of the vitamin $\mathrm{C}$ moiety and the 6-hydroxyl group of the vitamin $\mathrm{E}$ moiety.

\section{Experimental}

All of the solvents and reagents used were of reagent grade; in cases where further purification was required, the standard procedures were followed. ${ }^{26)}$ TLC was performed on precoated Silica-gel $60 \mathrm{~F}_{254}$ plates (Art. 5554, E. Merck). Silica gel ( $300-200$ mesh, Wakogel C-300) was used for Silica-gel chromatography, and the ratio of silica gel to the compound was in the range of $30: 1-100: 1$. Elemental analyses were performed by the Advanced Center for Chemical Analysis of Ehime 
University. ${ }^{1} \mathrm{H}-\mathrm{NMR}$ spectra and ${ }^{13} \mathrm{C}-\mathrm{NMR}$ spectra were obtained on JEOL GSX-270 and Varian Gemini-300 instruments. ${ }^{1} \mathrm{H}-\mathrm{NMR}$ spectra were recorded relative to internal tetramethylsilane $\left(\delta=0.0\right.$ in $\mathrm{CDCl}_{3}$ or DMSO- $\left.d_{6}\right)$ or sodium 3-(trimethylsilyl) propionate-2,2,3,3- $d_{4}(\delta=0.0$ in $\left.\mathrm{D}_{2} \mathrm{O}\right) \cdot{ }^{13} \mathrm{C}$-NMR spectra were recorded with $\mathrm{CDCl}_{3}(\delta=77.0)$ or dioxane $(\delta=67.3)$ as an internal standard. IR spectra were recorded on a Shimadzu IR-460 spectrometer. The melting points were recorded on a Yanaco MP-500V micro melting point apparatus without correction. UV-vis spectra were measured on a Shimadzu UV-1200V and UV-1600 spectrometer using a plastic or quartz cell of $1 \mathrm{~mm}$ pathlength. Optical rotation was measured using a Horiba SEPA-300 polarimeter with a sodium lamp ( $589 \mathrm{~nm})$. The HPLC analysis was carried out on Shim-pack CLC-ODS columns $(6 \mathrm{~mm}$ i.d. $\times 150 \mathrm{~mm}$ length, Wako Pure Chemical Industries Ltd.) with a system consisting of a Shimadzu LC-6A pump, SPD-6A UV spectrophotometric detector, SCL-6A system controller, and C-R4A Chromatopac. The eluent was $\mathrm{MeOH}: \mathrm{H}_{2} \mathrm{O}=95: 5(\mathrm{v} / \mathrm{v})$, flow rate $1.0 \mathrm{ml} / \mathrm{min}$, and detection was at $254 \mathrm{~nm}$.

5,6-O-Isopropylidene-L-ascorbic Acid (4) This was synthesized in $75 \%$ yield from 3 according to the procedure of Jung et $^{2} .^{25)}: \mathrm{mp} 208$ $210^{\circ} \mathrm{C}$ (lit. mp $217-222^{\circ} \mathrm{C},{ }^{25)} 201-203{ }^{\circ} \mathrm{C},{ }^{16 b)} 202-204^{\circ} \mathrm{C},{ }^{17)} 204$ $\left.206^{\circ} \mathrm{C}^{27)}\right) \cdot[\alpha]_{\mathrm{D}}^{20}+25.3^{\circ}\left(c=1.0, \mathrm{H}_{2} \mathrm{O}\right) .{ }^{1} \mathrm{H}-\mathrm{NMR}\left(\mathrm{D}_{2} \mathrm{O}\right) \delta: 1.37(6 \mathrm{H}$, s, acetonide), $4.17\left(1 \mathrm{H}, \mathrm{dd}, J_{65}=5.0,9.1 \mathrm{~Hz}\right), 4.31\left(1 \mathrm{H}, \mathrm{dd}, J_{65}=7.2\right.$, $9.1 \mathrm{~Hz}), 4.59\left(1 \mathrm{H}\right.$, ddd, $\left.J_{54}=2.3 \mathrm{~Hz}, J_{56}=5.0,7.3 \mathrm{~Hz}\right), 4.91(1 \mathrm{H}, \mathrm{d}$, $\left.J_{45}=2.4 \mathrm{~Hz}\right) .{ }^{13} \mathrm{C}-\mathrm{NMR}\left(\mathrm{D}_{2} \mathrm{O}\right) \delta: 26.7(\mathrm{q}), 27.5(\mathrm{q}), 67.8(\mathrm{t}), 75.7(\mathrm{~d})$, 78.5 (d), 113.5 (s), 120.5 (s), 158.4 (s), 176.1 (s). IR (KBr) cm ${ }^{-1}: 3300$, $3000,1757,1667,1100$.

3-O-Benzyl-5,6- $O$-isopropylidene-L-ascorbic Acid (5) A mixture of 4 $(21.6 \mathrm{~g}, 99.9 \mathrm{mmol})$ and $\mathrm{KHCO}_{3}(10.2 \mathrm{~g}, 101.9 \mathrm{mmol})$ in DMF $(50 \mathrm{ml})$ was stirred for $10 \mathrm{~min}$ at room temperature. Benzyl bromide $(17.0 \mathrm{~g}$, $99.9 \mathrm{mmol}$ ) was added dropwise, and the mixture was vigorously stirred for $12 \mathrm{~h}$ at room temperature. The reaction mixture was diluted with $\mathrm{H}_{2} \mathrm{O}$ (5-fold) and extracted with AcOEt. The combined layers were thoroughly washed with brine, dried over anhydrous $\mathrm{Na}_{2} \mathrm{SO}_{4}$, and evaporated in vacuo. The semisolid product was recrystallized from isopropyl ether to give 5 (14.3 g, $47 \%$ yield): $\mathrm{mp} 105-106^{\circ} \mathrm{C}$ (lit. ${ }^{17,27)}$ mp 105-106 $\left.{ }^{\circ} \mathrm{C}\right) .[\alpha]_{\mathrm{D}}^{20}+22.0^{\circ}(c=1.0, \mathrm{MeOH}) .{ }^{1} \mathrm{H}-\mathrm{NMR}\left(\mathrm{CDCl}_{3}\right) \delta$ : $1.36\left(3 \mathrm{H}, \mathrm{s}\right.$, acetonide), $1.39\left(3 \mathrm{H}, \mathrm{s}\right.$, acetonide), $4.02\left(1 \mathrm{H}, \mathrm{dd}, J_{65}=6.72\right.$, $8.54 \mathrm{~Hz}), 4.10\left(1 \mathrm{H}, \mathrm{dd}, J_{65}=6.72,8.54 \mathrm{~Hz}\right), 4.26\left(1 \mathrm{H}, \mathrm{dt}, J_{54}=3.66 \mathrm{~Hz}\right.$, $\left.J_{56}=6.72,8.54 \mathrm{~Hz}\right), 4.57\left(1 \mathrm{H}, \mathrm{d}, J_{45}=3.66 \mathrm{~Hz}\right), 5.52(2 \mathrm{H}$, two d, benzyl), $7.35-7.42\left(5 \mathrm{H}, \mathrm{m}\right.$, aromatic). ${ }^{13} \mathrm{C}-\mathrm{NMR}\left(\mathrm{CDCl}_{3}\right) \delta: 25.6(\mathrm{q}), 25.9(\mathrm{q})$, $65.3(\mathrm{t}), 73.5(\mathrm{t}), 74.2(\mathrm{~d}), 75.9(\mathrm{~d}), 110.3(\mathrm{~s}), 119.9(\mathrm{~s}), 128.1$ (d), 128.2 (d), 128.6 (d), 128.7 (d), 129.7 (d), 130.2 (d), 145.2 (s), 171.8 (s). IR (KBr) $\mathrm{cm}^{-1}: 3500,3000,1764,1695,1120,1050$.

5-Benzyloxy-2-hydroxymethyl-4H-pyran-4-one (7) This was synthesized in $87 \%$ yield from 6 according to the procedure of Kawase et al. ${ }^{24 a)}$ : mp 132-133 ${ }^{\circ} \mathrm{C}$ (lit. mp $132^{\circ} \mathrm{C}^{24 a)} 134-136^{\circ} \mathrm{C}^{24 b)}$ ). ${ }^{1} \mathrm{H}-\mathrm{NMR}$ (DMSO- $\left.d_{6}\right) \delta: 4.26\left(2 \mathrm{H}, \mathrm{s}, \mathrm{C}-5-\mathrm{CH}_{2}\right), 4.94(2 \mathrm{H}, \mathrm{s}$, benzyl), $5.60(1 \mathrm{H}, \mathrm{t}$, $\mathrm{OH}), 6.31(1 \mathrm{H}, \mathrm{s}, \mathrm{C}-6), 7.38(5 \mathrm{H}, \mathrm{s}$, aromatic), $8.12(1 \mathrm{H}, \mathrm{s}, \mathrm{C}-3)$.

5-Benzyloxy-2-chloromethyl-4H-pyran-4-one (8) A mixture of 7 (37.5 $\mathrm{g}, 161.3 \mathrm{mmol})$ and triphenylphosphine $(42.3 \mathrm{~g}, 161.3 \mathrm{mmol})$ in $\mathrm{CCl}_{4}$ $(1000 \mathrm{ml})$ was heated under reflux, and vigorously stirred for $48 \mathrm{~h}$. After the solvent had been evaporated in vacuo, the residue was recrystallized from $\mathrm{CH}_{2} \mathrm{Cl}_{2}$ to give $8\left(29.5 \mathrm{~g}, 73 \%\right.$ yield): $\mathrm{mp} 115-116^{\circ} \mathrm{C}$ (lit. ${ }^{28)} \mathrm{mp}$ $\left.118-120^{\circ} \mathrm{C}\right) .{ }^{1} \mathrm{H}-\mathrm{NMR}\left(\mathrm{CDCl}_{3}\right) \delta: 4.27\left(2 \mathrm{H}, \mathrm{s}, \mathrm{C}-5-\mathrm{CH}_{2}\right), 5.06(2 \mathrm{H}, \mathrm{s}$, benzyl), $6.45(1 \mathrm{H}, \mathrm{s}, \mathrm{C}-6), 7.34(5 \mathrm{H}, \mathrm{s}$, aromatic), $7.54(1 \mathrm{H}, \mathrm{s}, \mathrm{C}-3)$.

3-O-Benzyl-2-O-(5-benzyloxy-4H-pyran-4-one-2-methyl)-5,6- $O$-isopropylidene-L-ascorbic Acid (9) To a mixture of $5(12.3 \mathrm{~g}, 40.2 \mathrm{mmol})$ and $8(10.0 \mathrm{~g}, 39.9 \mathrm{mmol})$ in DMF $(50 \mathrm{ml})$ was added $\mathrm{K}_{2} \mathrm{CO}_{3}(5.5 \mathrm{~g}$, $39.8 \mathrm{mmol}$ ). The mixture was vigorously stirred for $16 \mathrm{~h}$ at room temperature, then diluted with $\mathrm{H}_{2} \mathrm{O}$ (5-fold) and extracted with AcOEt. The combined organic layers were thoroughly washed with brine, dried over anhydrous $\mathrm{Na}_{2} \mathrm{SO}_{4}$, and evaporated in vacuo. The residue was chromatographed $\left(\mathrm{SiO}_{2}\right.$, hexane : $\left.\mathrm{AcOEt}=3: 2\right)$ to give $9(17.6 \mathrm{~g}, 92 \%$ yield): ${ }^{1} \mathrm{H}-\mathrm{NMR}\left(\mathrm{CDCl}_{3}\right) \delta: 1.37(6 \mathrm{H}, \mathrm{s}$, acetonide), 3.69-4.09 $(2 \mathrm{H}, \mathrm{m}$, $\left.J_{65}=6.71,8.64 \mathrm{~Hz}\right), 4.22\left(1 \mathrm{H}, \mathrm{dd}, J_{54}=3.66 \mathrm{~Hz}, J_{56}=6.72,8.64 \mathrm{~Hz}\right), 4.55$ $\left(1 \mathrm{H}, \mathrm{d}, J_{45}=3.66 \mathrm{~Hz}\right), 4.81\left(2 \mathrm{H}, \mathrm{s}\right.$, kojic acid $\left.\mathrm{C}-5-\mathrm{CH}_{2}\right), 5.02(2 \mathrm{H}, \mathrm{s}$, benzyl), $5.39(2 \mathrm{H}, \mathrm{s}$, benzyl), $6.40(1 \mathrm{H}, \mathrm{s}$, kojic acid C-6), $7.33(5 \mathrm{H}, \mathrm{m}$, aromatic), $7.47(\mathrm{lH}, \mathrm{s}$, kojic acid $\mathrm{C}-3) .{ }^{13} \mathrm{C}-\mathrm{NMR}\left(\mathrm{CDCl}_{3}\right) \delta: 25.6$ (acetonide), 25.9 (acetonide), 65.2 (C-6), 68.2 (C-5), 68.4 (kojic acid C-5- $\mathrm{CH}_{2}$ ), 72.3, 74.7, 75.8 (C-4), 110.3 (acetonide), 112.5 (kojic acid C-3), 120.9 (C-2), 127.5, 127.6, 127.8, 127.9, 128.1, 128.2, 128.4, 128.5, 128.7, 128.8, 137.4, 138.5, 139.8 (kojic acid C-6), 146.0 (kojic acid C-5), 155.6 (C-3), 162.6 (kojic acid C-2), 168.6 (C-1), 173.8 (kojic acid C-1). Anal. Calcd for $\mathrm{C}_{29} \mathrm{H}_{28} \mathrm{O}_{9}$ : C, 66.92; H, 5.42. Found: C, 66.97; H, 5.39.
3-O-Benzyl-2-O-(5-benzyloxy-4H-pyran-4-one-2-methyl)-L-ascorbic Acid (10) A solution of $9(17.6 \mathrm{~g}, 33.8 \mathrm{mmol})$ in THF $(50 \mathrm{ml})$ was treated with $35 \% \mathrm{HCl}(5 \mathrm{ml})$ at room temperature. The mixture was stirred for $1 \mathrm{~h}$ at room temperature. The reaction was quenched by the addition of saturated $\mathrm{NaHCO}_{3}$ solution. An aqueous layer was extracted with AcOEt. The combined layers were washed with brine and dried over anhydrous $\mathrm{Na}_{2} \mathrm{SO}_{4}$. After the solvent was evaporated in vacuo, the residue was chromatographed $\left(\mathrm{SiO}_{2}\right.$, hexane: $\left.\mathrm{AcOEt}=1: 4\right)$ to give 10 (15.9 g, $98 \%$ yield): $\mathrm{mp} 150-152{ }^{\circ} \mathrm{C} .{ }^{1} \mathrm{H}-\mathrm{NMR}\left(\mathrm{CDCl}_{3}\right) \delta: 3.85(2 \mathrm{H}, \mathrm{m}$, $\left.J_{65}=6.72 \mathrm{~Hz}\right), 4.22\left(1 \mathrm{H}, \mathrm{ddd}, J_{54}=3.66 \mathrm{~Hz}, J_{56}=6.72 \mathrm{~Hz}\right), 4.55(1 \mathrm{H}, \mathrm{d}$ $\left.J_{45}=3.66 \mathrm{~Hz}\right), 4.83\left(2 \mathrm{H}, \mathrm{s}\right.$, kojic acid C-5- $\left.\mathrm{CH}_{2}\right), 5.04(2 \mathrm{H}, \mathrm{s}$, benzyl $)$, $5.39(2 \mathrm{H}, \mathrm{s}$, benzyl $), 6.41(1 \mathrm{H}, \mathrm{s}$, kojic acid $\mathrm{C}-6), 7.35(5 \mathrm{H}, \mathrm{m}$, aromatic), $7.49\left(1 \mathrm{H}, \mathrm{s}\right.$, kojic acid C-3). ${ }^{13} \mathrm{C}-\mathrm{NMR}\left(\mathrm{CDCl}_{3}\right) \delta: 61.9(\mathrm{C}-6), 68.4(\mathrm{C}-5)$, 68.5 (kojic acid C-5- $\mathrm{CH}_{2}$ ), 72.3, 74.7, $75.7(\mathrm{C}-4), 112.5$ (kojic acid C-3), 121.0 (C-2), 127.4, 127.6, 127.8, 127.9, 128.0, 128.2, 128.4, 128.5, 128.7, 128.8, 137.6, 138.5, 139.9 (kojic acid C-6), 146.1 (kojic acid C-5), 155.8 (C-3), 162.6 (kojic acid C-2), 168.6 (C-1), 173.9 (kojic acid C-1). Anal. Calcd for $\mathrm{C}_{26} \mathrm{H}_{24} \mathrm{O}_{9}$ : C, 65.00; $\mathrm{H}, 5.03$. Found: $\mathrm{C}, 64.96 ; \mathrm{H}, 4.99$.

2-O-(5-Hydroxy-4H-pyran-4-one-2-methyl)-L-ascorbic Acid (1) A solution of $10(15.9 \mathrm{~g}, 33.1 \mathrm{mmol})$ in $\mathrm{MeOH}(100 \mathrm{ml})$ containing $5 \% \mathrm{Pd}-\mathrm{C}$ $(1.5 \mathrm{~g})$ was vigorously stirred for $3 \mathrm{~h}$ at room temperature under a hydrogen atmosphere. After the catalyst had been removed by filtration, the filtrate was evaporated to dryness in vacuo. The residue was dissolved in $\mathrm{H}_{2} \mathrm{O}$ and this solution was washed with AcOEt. The aqueous layer was evaporated in vacuo and the residue was recrystallized from acetone to give $1(8.3 \mathrm{~g}, 84 \%$ yield $)$ : $\mathrm{mp} 222-224^{\circ} \mathrm{C}$. $[\alpha]_{\mathrm{D}}^{25}+23.4^{\circ}\left(c=0.4, \mathrm{H}_{2} \mathrm{O}\right)$. UV $\lambda_{\max }\left(\mathrm{H}_{2} \mathrm{O}\right) \mathrm{nm}(\log \varepsilon): 262.0$ (3.96), 217.0 (3.90). ${ }^{1} \mathrm{H}-\mathrm{NMR}$ $\left(\right.$ DMSO- $\left.d_{6}\right) \delta: 3.45\left(2 \mathrm{H}, \mathrm{m}, J_{65}=6.72 \mathrm{~Hz}\right), 3.80\left(1 \mathrm{H}, \mathrm{ddd}, J_{54}=3.66 \mathrm{~Hz}\right.$, $\left.J_{56}=6.72 \mathrm{~Hz}\right), 4.83\left(3 \mathrm{H}, \mathrm{s}, J_{45}=3.66 \mathrm{~Hz}\right.$, kojic acid C-5 $\left.-\mathrm{CH}_{2}\right), 6.60(1 \mathrm{H}$, s, kojic acid C-6), $8.08(1 \mathrm{H}, \mathrm{s}$, kojic acid C-3), 9.01-9.40 $(1 \mathrm{H}, \mathrm{s}, \mathrm{OH})$; ${ }^{13} \mathrm{C}-\mathrm{NMR}$ (DMSO- $d_{6}$ ) $\delta: 61.8$ (C-6), 68.4 (C-5), 68.5 (kojic acid C-5- $\mathrm{CH}_{2}$ ), 74.9 (C-4), 112.6 (kojic acid C-3), 119.2 (C-2), 139.8 (kojic acid C-6), 146.0 (kojic acid C-5), 160.4 (C-3), 162.6 (kojic acid C-2), 169.2 (C-1), 173.8 (kojic acid C-1). IR (KBr) cm-1': 3440, 3325, 3170, 2930, 1766, 1724, 1670, 1648, 1460, 1377, 1215, 1138, 1044. Anal. Calcd for $\mathrm{C}_{12} \mathrm{H}_{12} \mathrm{O}_{9}$ : C, 48.01; $\mathrm{H}, 4.03$. Found: $\mathrm{C}, 48.04 ; \mathrm{H}, 3.99$.

3,4-Dihydro-2,5,7,8-tetramethyl-6-(oxiranylmethoxy)-2-(4,8,12-trimethyltridecyl)-2H-1-benzopyran (12) Finely powdered $\mathrm{NaOH}(0.2 \mathrm{~g}$, $4.1 \mathrm{mmol})$ was added to a mixture of $11(1.8 \mathrm{~g}, 4.1 \mathrm{mmol})$ and $S$-(+)-epichlorohydrin $(1.9 \mathrm{~g}, 20.5 \mathrm{mmol})$ in dioxane $(3 \mathrm{ml})$. The mixture was heated under reflux, vigorously stirred for $7 \mathrm{~h}$, then diluted with $\mathrm{H}_{2} \mathrm{O}$ (2-fold) and extracted with ether. The combined layers were thoroughly washed with brine, dried over anhydrous $\mathrm{Na}_{2} \mathrm{SO}_{4}$, and evaporated in vacuo. The residue was chromatographed $\left(\mathrm{SiO}_{2}\right.$, hexane : $\mathrm{AcOEt}=10: 1)$ to give $12(1.8 \mathrm{~g}, 92 \%$ yield $):{ }^{13} \mathrm{C}-\mathrm{NMR}\left(\mathrm{CDCl}_{3}\right)$ $\delta: 11.9$ (C-5-Me), 12.1 (C-7-Me), 13.0 (C-8-Me), 19.7 (C-4'-Me), 19.8 (C-8'-Me), 20.6 (C-4), $21.1\left(\mathrm{C}-2^{\prime}\right), 22.7$ (C-13', 12'-Me,), 22.8 (C-2-Me), 24.5 (C-6'), 24.9 (C-10'), 28.0 (C-12'), $31.0(\mathrm{C}-3), 32.8\left(\mathrm{C}-4^{\prime}\right), 32.9\left(\mathrm{C}-8^{\prime}\right)$, $37.4\left(\mathrm{C}-3^{\prime}, 5^{\prime}, 7^{\prime}, 9^{\prime}\right), 37.5\left(\mathrm{C}-11^{\prime}\right), 40.4\left(\mathrm{C}-1^{\prime}\right), 64.2\left(\mathrm{OCH}_{2}\right), 68.9\left(\mathrm{OCH}_{2}\right)$, $70.3(\mathrm{OCH}), 74.7$ (C-2), 117.8 (C-7), 123.4 (C-8), 125.7 (C-5), 127.4 (C-4a), 147.5 (C-6), 148.2 (C-8a). IR (neat) $\mathrm{cm}^{-1}:$ :2930, 1256, 1158. Anal. Calcd for $\mathrm{C}_{32} \mathrm{H}_{54} \mathrm{O}_{3}: \mathrm{C}, 78.96 ; \mathrm{H}, 11.18$. Found: C, 78.73; H, 10.94 .

3-O-[3-[[3,4-Dihydro-2,5,7,8-tetramethyl-2-(4,8,12-trimethyltridecyl)2H-1-benzopyran-6-yl] oxy]-2-hydroxypropyl]-5,6- $O$-isopropylidene-Lascorbic Acid (13) A mixture of $4(4.3 \mathrm{~g}, 19.9 \mathrm{mmol}), 12(8.1 \mathrm{~g}, 16.6$ $\mathrm{mmol})$, and 4-dimethylaminopyridine $(0.2 \mathrm{~g}, 1.6 \mathrm{mmol})$ in dioxane $(40 \mathrm{ml})$ was treated with $\mathrm{NaHCO}_{3}(1.4 \mathrm{~g}, 16.7 \mathrm{mmol})$ and the whole was heated under reflux and vigorously stirred for $24 \mathrm{~h}$. The reaction mixture was washed with $\mathrm{H}_{2} \mathrm{O}$ (2-fold) and extracted with AcOEt. The combined layers were thoroughly washed with brine, dried over anhydrous $\mathrm{Na}_{2} \mathrm{SO}_{4}$, and evaporated in vacuo. The residue was chromatographed $\left(\mathrm{SiO}_{2}\right.$, hexane: $\mathrm{AcOEt}=5: 1)$ to give $13(7.0 \mathrm{~g}, 60 \%$ yield $):{ }^{13} \mathrm{C}-\mathrm{NMR}\left(\mathrm{CDCl}_{3}\right)$ $\delta: 11.5$ (tocopherol C-5-Me), 12.4 (tocopherol C-7-Me), 13.0 (tocopherol C-8-Me), 19.4 (tocopherol C-4'-Me), 19.6 (tocopherol C-8'-Me), 20.9 (tocopherol C-4), 20.9 (tocopherol C-2'), 22.5 (tocopherol C-13', 12'-Me), 23.4 (tocopherol C-2-Me), 24.3 (tocopherol C-6'), 24.7 (tocopherol C-10'), 25.4 (acetonide), 25.5 (acetonide), 27.8 (tocopherol C-12'), 31.1 (tocopherol C-3), 32.7 (tocopherol C-4'), 32.9 (tocopherol C-8'), 37.3 (tocopherol C-3', 5', 7', 9'), 39.3 (tocopherol C-11'), 40.3 (tocopherol C-1'), $63.0\left(\mathrm{OCH}_{2}\right), 68.1\left(\mathrm{OCH}_{2}\right), 69.2(\mathrm{OCH}), 69.8(\mathrm{C}-6), 72.2(\mathrm{C}-5)$, 74.7 (tocopherol C-2), 76.3 (C-4), 109.1 (acetonide), 117.8 (tocopherol C-7), 120.9 (C-2), 123.0 (tocopherol C-8), 125.8 (tocopherol C-5), 127.4 (tocopherol C-4a), 147.3 (tocopherol C-6), 148.0 (tocopherol C-8a), 151.1 
(C-3), 172.3 (C-1). IR (neat) $\mathrm{cm}^{-1}: 3330,2935,1760,1697,1255,1217$, 1152, 1088. Anal. Calcd for $\mathrm{C}_{41} \mathrm{H}_{66} \mathrm{O}_{9}: \mathrm{C}, 70.05 ; \mathrm{H}, 9.46$. Found: $\mathrm{C}$, $70.08 ; \mathrm{H}, 9.51$.

3-O-[3-[[3,4-Dihydro-2,5,7,8-tetramethyl-2-(4,8,12-trimethyltridecyl)2H-1-benzopyran-6-yl]oxy]-2-hydroxypropyl]-L-ascorbic Acid (2) A solution of $13(6.0 \mathrm{~g}, 8.5 \mathrm{mmol})$ in dioxane $(100 \mathrm{ml})$ was treated with $35 \%$ $\mathrm{HCl}(10 \mathrm{ml})$ at room temperature. The mixture was stirred for $6 \mathrm{~h}$ at room temperature. The reaction was quenched by the addition of saturated $\mathrm{NaHCO}_{3}$ solution. The aqueous layer was extracted with AcOEt. The combined layers were washed with brine and dried over anhydrous $\mathrm{Na}_{2} \mathrm{SO}_{4}$. The solvent was evaporated in vacuo, and the residue was chromatographed $\left(\mathrm{SiO}_{2}\right.$, hexane : $\left.\mathrm{AcOEt}=1: 1\right)$ to give $2(5.2 \mathrm{~g}, 92 \%$ yield): $\mathrm{mp} 90-92{ }^{\circ} \mathrm{C} .{ }^{13} \mathrm{C}$-NMR $\left(\mathrm{CDCl}_{3}\right) \delta: 11.5$ (tocopherol C-5-Me) 11.6 (tocopherol C-7-Me), 12.4 (tocopherol C-8-Me), 19.5 (tocopherol C-4'-Me), 19.6 (tocopherol C-8'-Me), 20.4 (tocopherol C-4), 20.9 (tocopherol C-2'), 22.5 (tocopherol C-13'), 22.6 (tocopherol C-12'-Me), 23.4 (tocopherol C-2-Me), 24.3 (tocopherol C-6'), 24.7 (tocopherol C-10'), 27.8 (tocopherol C-12'), 31.1 (tocopherol C-3), 32.6 (tocopherol C-4') 32.7 (tocopherol C-8'), 37.2 (tocopherol C-9'), 37.3 (tocopherol C-3', 5', $\left.7^{\prime}\right), 39.3$ (tocopherol C-11'), 40.3 (tocopherol C-1'), $63.0\left(\mathrm{OCH}_{2}\right)$, 68.1 $\left(\mathrm{OCH}_{2}\right), 69.2(\mathrm{OCH}), 69.8(\mathrm{C}-6), 72.2(\mathrm{C}-5), 74.7$ (tocopherol C-2), 76.3 (C-4), 117.6 (tocopherol C-7), 119.7 (C-2), 122.9 (tocopherol C-8), 125.7 (tocopherol C-5), 127.6 (tocopherol C-4a), 147.3 (tocopherol C-6), 148.1 (tocopherol C-8a), $151.0(\mathrm{C}-3), 172.3(\mathrm{C}-1)$. IR (neat) $\mathrm{cm}^{-1}: 3360,2960$, 1758, 1692, 1255, 1161, 1088. Anal. Calcd for $\mathrm{C}_{38} \mathrm{H}_{62} \mathrm{O}_{9}: \mathrm{C}, 69.85 ; \mathrm{H}$, 9.43. Found: C, 69.48; H, 9.49.

2-O-Octadecyl-L-ascorbic Acid (17) This was synthesized in three steps from 4 according to the procedure of Kato et al. ${ }^{17)}$ : $\mathrm{mp} 127-128^{\circ} \mathrm{C}$ (lit. ${ }^{17)} \mathrm{mp} 127-128^{\circ} \mathrm{C}$ ).

Physicochemical and Biological Experiments. Measurement of Thermal Stability in Aqueous Solution The test compounds were dissolved in a solution of EtOH: $\mathrm{H}_{2} \mathrm{O}=1: 1(\mathrm{v} / \mathrm{v})$ to give a concentration of $1 \mathrm{~mol} \%$ solution. The resulting solution was stored at $60^{\circ} \mathrm{C}$ for 1 month, and $0.05 \mathrm{ml}$ samples were taken at 1 -month intervals for 3 months. The concentration of the test compounds was measured by HPLC. The difference from initial concentration was taken as the remaining ratio. The results are shown in Table 1.

Measurement of Inhibitory Activity against Tyrosinase-Catalyzed Oxidation of L-Tyrosine ${ }^{29)}$ A mixture of $10^{-3} \mathrm{M}$ test compound aqueous solution $(0.5 \mathrm{ml}), 0.3 \mathrm{mg} / \mathrm{ml}$ L-tyrosine $(0.5 \mathrm{ml})$ aqueous solution, and potassium phosphate buffer solution $(\mathrm{pH} 6.8,2.0 \mathrm{ml})$ was heated for $10 \mathrm{~min}$ at $37^{\circ} \mathrm{C}$. An aqueous solution $(0.02 \mathrm{ml})$ of mushroom tyrosinase $(1.0 \mathrm{mg} / \mathrm{ml}, 2000$ units $/ \mathrm{mg})$ was added and the whole was incubated at $37^{\circ} \mathrm{C}$. After $20 \mathrm{~min}$, the absorbance (optical density: OD) of the reaction mixture was measured at $475 \mathrm{~nm}$, the absorption maximum of dopachrome. The ratio of inhibitory activity was estimated by use of the following equation. The results are shown in Table 2.

$$
\begin{aligned}
\text { inhibition }(\%)= & {[(\text { control OD })-(\text { sample OD })] /[\text { (control OD }) } \\
& -(\text { blank OD })] \times 100
\end{aligned}
$$

Measurement of Inhibitory Activity against Tyrosinase-Catalyzed Oxidation of L-Dopa ${ }^{29)}$ A $10^{-4}, 3 \times 10^{-4}$, or $10^{-3} \mathrm{M}$ aqueous solution of the test compound $(0.2 \mathrm{ml})$ was added to a mixture of L-dopa $(0.5 \mathrm{mg} / \mathrm{ml})$ aqueous solution $(0.5 \mathrm{ml})$ and potassium phosphate buffer solution ( $\mathrm{pH} 6.8,2.0 \mathrm{ml}$ ), and the mixture was heated for $5 \mathrm{~min}$ at $37^{\circ} \mathrm{C}$. An aqueous solution $(0.05 \mathrm{ml})$ of mushroom tyrosinase $(1.0 \mathrm{mg} / \mathrm{ml}$, 2000 units $/ \mathrm{mg}$ ) was added and the whole was incubated at $37^{\circ} \mathrm{C}$. After $1 \mathrm{~min}$, the absorbance of the reaction mixture was measured at $475 \mathrm{~nm}$, the absorbance maximum of dopachrome. The ratio of inhibitory activity was estimated by use of the above equation. The results are shown in Table 3.

Measurement of the Reducing Activity of the Stable Radical DPPH ${ }^{30}$ The test compound in DMF $(3 \mathrm{ml})$ was added to a solution of DPPH $\left(10^{-4} \mathrm{M}\right)$ in EtOH to prepare $10^{-6}, 10^{-5}, 10^{-4}$, and $10^{-3} \mathrm{M}$ sample solutions. After $20 \mathrm{~min}$ at $25^{\circ} \mathrm{C}$, the absorbance at $517 \mathrm{~nm}$ was measured. The difference in absorbance from the control, without test compound, was taken as the reducing activity. The results are shown in Table 4.

Measurement of the Active Oxygen Scavenging Activity. NBT Method ${ }^{31}$ A $10^{-6}, 10^{-5}, 10^{-4}$, or $10^{-3} \mathrm{M}$ aqueous solution of test compound $(0.1 \mathrm{ml})$ was added to a mixture containing $3 \times 10^{-3} \mathrm{M}$ xanthine solution in sodium carbonate buffer solution $(\mathrm{pH} 10.2,0.1 \mathrm{ml}), 7.5 \times 10^{-4} \mathrm{M}$ NBT aqueous solution $(0.1 \mathrm{ml})$, sodium carbonate buffer solution $(\mathrm{pH} \mathrm{10.2,}$ $0.1 \mathrm{ml}$ ), and $3 \times 10^{-3} \mathrm{M}$ ethylenediaminetetraacetic acid disodium salt (EDTA) aqueous solution $(0.1 \mathrm{ml})$. Further, 1\% (v/v) XOD from buttermilk ( $\geq 0.5$ units $/ \mathrm{mg}$ protein) in $0.15 \%(\mathrm{w} / \mathrm{v})$ bovine serum albumin (BSA) aqueous solution $\left(1.6 \times 10^{-2} \mathrm{ml}\right)$ was added to the above mixture, and the whole was incubated at $25^{\circ} \mathrm{C}$. The enzymatic reaction was stopped at the end of $20 \mathrm{~min}$ with $6 \mathrm{mM} \mathrm{CuCl}{ }_{2}$ aqueous solution $(0.1 \mathrm{ml})$, and the absorbance of the reaction mixture was measured at $560 \mathrm{~nm}$, the absorbance maximum of diformazan. The difference in absorbance from the control, without test compound, was taken as the scavenging activity. The results are shown in Table 5 .

Acknowledgment The authors thank Y. Fukai and M. Morioka (Kanto Denka Kogyo Co., Ltd.) for their assistance in the NMR measurements, and the Advanced Center for Chemical Analysis, Ehime University for elemental analyses.

\section{References}

1) Clark R. A., Leidal K. G., Pearson D. W., Nauseef W. M., J. Biol. Chem., 262, 4065-4074 (1987).

2) a) Keyse S. M., Emslie E. A., Nature (London), 359, 644-647 (1992); b) Basu A. K., Essigmann J. M., Chem. Res. Toxicol., 1, 1-18 (1988); c) Halliwell B., Gutteridge J. M. C., Trends Biochem. Sci. (Pers. Ed.), 11, 372-375 (1986); d) Youngman R. Y., ibid., 9, 280-283 (1984).

3) a) Niwa Y., Dermatologica, 179 (suppl. 1), 101-106 (1989); b) McCord J. M., N. Engl.J. Med., 312, 159-163 (1985); c) Hammond B., Kontos H. A., Hess M. L., Can. J. Physiol. Pharmacol., 63, 173-187 (1985); $d$ ) Halliwell B., Gutteridge J. M. C., Biochem. J., 222, 1-14 (1984); e) Burton K. P., McCord J. M., Ghai G., Am. J. Physiol., 246, H776-H783 (1984); f) Fridovich I., Annu. Rev. Pharmacol. Toxicol., 23, 239 (1983); g) Setlow R. B., Nature (London), 271, 713-717 (1978).

4) Orr W. C., Sohal R. S., Science, 263, 1128-1130 (1994).

5) a) Tomita Y., Hariu A., Kato C., Seiji M., J. Invest. Dermatol., 82, 573-576 (1984); b) Tomita Y., J. Act. Oxyg. Free Rad., 3, 284-289 (1992).

6) a) Imokawa G., Mishima Y., Cancer Res., 42, 1994-2002 (1982); b) Huber M., Hintermann G., Lerch K., Biochemistry, 24, 6038-6044 (1985).

7) Woodward B., Zakaria M. N., J. Mol. Cell. Cardiol., 17, 485-493 (1985).

8) a) Frimer A. A., Gilinsky-Sharon P., J. Org. Chem., 60, 2796-2801 (1995); b) Bendich A., Machlin L. J., Scandurra O., Burton G. W., Wayner D. D. M., Adv. Free Radical Biol. Med., 2, 419-444 (1986); c) Frei B., Stocker R., Ames B. N., Proc. Natl. Acad. Sci. U.S.A., 85, 9748-9752 (1988).

9) Ishida Y., Fragrance J., 1983, 28-34.

10) a) Rose R. C., Bode A. M., FASEB J., 7, 1135-1142 (1993); b) Ames B. N., Shigenaga M. K., Hagen T. M., Proc. Nat. Acad. Sci. U.S.A., 90, 7915-7922 (1993).

11) Takashima H., Nomura H., Imai Y., Mima H., Am. Perfum. Cosmet., 86, 29-36 (1971).

12) a) Quadri S. F., Seib P. A., Deyoe C. W., Carbohydr. Res., 29, 259-264 (1973); b) Lee C. H., Seib P. A., Liang Y. T., Hoseney R. C., Deyoe C. W., ibid., 67, 127-138 (1978); c) Nomura H., Shimomura M., Morimoto S., Chem. Pharm. Bull., 19, 1433-1437 (1971)

13) a) Hata R., Senou H., J. Cell. Physiol., 138, 8-16 (1989); b) Niki E., Tsuchiya J., Tanimura R., Kamiya Y., Chem. Lett., 1982, 789-792; c) Kirby A. J., Varvoglis A. G., J. Am. Chem. Soc., 89, 415-423 (1967).

14) Tanaka M., Muto N., Yamamoto I., Biochim. Biophys. Acta, 1078. 127-132 (1991).

15) a) Nomura H., Sugimoto K., Chem. Pharm. Bull., 14, 1039-1044 (1966); b) Tanaka H., Yamamoto R., J. Pharm. Soc. Jpn., 86, $376-380$ (1966).

16) a) Nihro Y., Sogawa S., Sudo T., Miki T., Matsumoto H., Satoh T., Chem. Pharm. Bull., 39, 1731-1735 (1991); b) Nihro Y., Miyataka H., Sudo T., Miki T., Matsumoto H., Satoh T., J. Med. Chem., 34, 2152-2157 (1991).

17) Kato K., Terao S., Shimamoto N., Hirata M., J. Med. Chem., 31, 793-798 (1988).

18) a) Packer J. E., Slater T. F., Willson R. L., Nature (London), 278, 737-738 (1979); b) Mukai K., Nishimura M., Kikuchi S., J. Biol. Chem., 266, 274-278 (1991); c) Ginter E., Kosinova A., Hudecova A., Madaric A., Int. J. Vitam. Nutr. Res., 52, 55-59 (1982); d) 
Keith R. E., Chrisley B. M., Driskell J. A., Am. J. Clin. Nutr., 33, 2394-2395 (1980).

19) a) Grisar J. M., Marciniak G., Bolkenius F. N., Verne-Mismer J., Wagner E. R., J. Med. Chem., 38, 2880-2886 (1995); b) Wimalasena K., Mahindaratne M. P. D., J. Org. Chem., 59, 3427-3432 (1994); c) Cabral J., Haake P., ibid., 53, 5742-5750 (1988); d) Sekine M., Futatsugi T., Hata T., ibid., 47, 3453-3456 (1982).

20) For reviews: a) Seib P. A., Int. J. Vitam. Nutr. Res., Suppl., 27, 259-306 (1985); b) Andrews G. C., Crawford T., Adv. Chem. Ser., 200, 59-79 (1982); c) Tolbert B. M., Downing M., Carison R. W., Knight M. K., Baker E. M., Ann. N.Y. Acad. Sci., 258, 48-69 (1975); d) Davies M. B., Polyhedron, 11, 285-321 (1992).

21) Tojo K., Lee A.-R. C., J. Soc. Cosmet. Chem., 38, 333-339 (1987).

22) a) Mishima Y., Hatta S., Ohyama Y., Inazu M., Pigm. Cell Res., 1, 367-374 (1988); b) Izumida H., Fragrance J., 1989, 109-111; c) Higa Y., ibid., 1983, 40—44; d) Murakami Y., Mera K., Bull. Chem. Soc. Jpn., 39, 396-397 (1966); e) Murakami Y., Mera K., ibid., 35, 52-56 (1962); f) Murakami Y., Mera K., J. Inorg. Nucl. Chem., 24, 679-688 (1962).
23) Akiu S., Suzuki Y., Fujinuma Y., Asahara T., Fukuda M., Proc. Jpn. Soc. Invest. Dermatol., 12, 138-139 (1988).

24) a) Kawase K., Hayashi K., Nippon Nogei Kagaku Kaishi, 46, 331 -334 (1972); b) Kalyanam N., Likhate M. A., Fuhrer H., Indian J. Chem., Sect. B, 30B, 358-359 (1991).

25) Jung M. E., Shaw T. J., J. Am. Chem. Soc., 102, 6304-6311 (1980).

26) Perrin D. D., Armarego W. L. F., Perrin D. R., Purification of Laboratory Chemicals; 2nd ed., Pergamon Press, Oxford, 1980.

27) a) Wimalasena K., Mahindaratne M. P. D., J. Org. Chem., 59, 3427-3432 (1994); b) Mawer I. M., Tetrahedron, 45, 5679-5702 (1989).

28) Thomas A. F., J. Chem. Soc., 1962, 439-442.

29) a) Pomerantz S. H., J. Biol. Chem., 238, 2351-2357 (1963); b) Lerner A. B., Fitzpatrick T. B., Calkins E., Summerson W. H., ibid., 187, 793-802 (1950).

30) Blois M. S., Nature (London), 181, 1199-1200 (1958)

31) a) Nishikimi M., Biochem. Biophys. Res. Commun., 63, 463-468 (1975); b) Beauchamp C., Fridovich I., Anal. Biochem., 44, 276-287 (1971). 